\title{
Regulations on Occupational Health and the Role of Labor Inspection
}

\section{Eneida Sema (Dervishi)}

Prof. As. Dr. Lecturer, Faculty of Law, University of Tirana

\begin{abstract}
Over the years the international community has developed a framework with international standards which intend to protect employees from injuries and occupational diseases. While progress is being achieved in preventing this problem, in many cases the rights contained in these standards are not fully applied or implemented in practice. In accordance with the need for prevention in this aspect, our Parliament adopted the Law "For Health and Safety at Work" in 2010 and greater attention is paid to 'safety at work regulations' by specific amendments to Albanian Labor Code taking place in 2015. ${ }^{1}$ The above legislative changes represent new challenge as it mostly states the 'prevention plan of measures', regardless of multiple difficulties which should be considered as well. Legislative measures and the national policies are implemented through by the State Labor Inspectorate but specific measures in respect of strengthening workplace through inspection and labor administration are in need. Labor Inspectorate needs to enforce collaboration with specific institutions and social partners and also providing technical assistance is another important aspect.
\end{abstract}

Keywords: safety, workplace, labor inspection, prevention

\section{Introduction}

All over the world, issues of occupational safety and health are presented nowadays as one of the most sensitive issues that deserve the proper attention from all the countries that implement the principles of safety and health, in respecting human rights to life as well as dignity.

Over the years the international community has developed a framework with international standards which intend to protect employees from injuries and occupational diseases.

\footnotetext{
${ }^{1}$ Specific amendments in this respect, to Albanian Labor Code are made by 'Law No 136/2015"
} 
According to ILO estimates, a worker dies from a work-related accident or disease every 15 seconds. Every day, some 6,300 workers die from occupational accidents or work-related diseases, amounting to more than 2.3 million deaths a year. Furthermore, over 313 million workers suffer non-fatal occupational injuries each year, or in other words 860,000 people are injured on the job every day. ${ }^{1}$

\section{Regulations on Occupational Health According to Albanian Legislation}

During the last decade in particular our country has approximated its legal framework with the European Union's 'acquis communitaire', in regard to implementing the Stabilizations and Association Agreement. Thus, in the field of occupational safety and health, the Law "On occupational safety and health" was adopted," as well as a series of regulations and by laws ${ }^{3}$ to facilitate its implementation, followed by amendments in the Labor Code of the Republic of Albania. ${ }^{4}$

In 2009 Albania implemented the 'Strategy for occupational safety and health 20092013', a document compiled in the spirit of international standards and internal problematic in this field which determines the relevant measures especially those in regard of enforced control.

Furthermore, we should mention that Albania ratified the majority of International Labour Organization's conventions, such as the Convention No. 155 "Occupational safety and health", of 1981, its protocol in 2002, Convention No. 187 /2006 "Promotional framework for occupational safety and health", as well as the Convention No. 167/1988 "Safety and health in construction".

Meanwhile, we can detect that the Convention No. 187 of the International Labour Organizations focuses in two main goals:

- Developing the preventive culture and

- Establishing a suitable system in a national range to administer occupational safety and health ${ }^{5}$

During the collaboration with representatives of governments from different countries, representatives of employers and employees, the International Labour

\footnotetext{
${ }^{1}$ www.ilo.org/publns, ILC.106/III/1B, International Labour Conference, 106 th session, 2017 : "Working together to promote a safe and healthy working environment" pg. 2, prgh. 5, International Labour Office, Geneva

${ }^{2}$ For more information see : www.qpz.gov.al, Official Journal of the Republic of Albania, published by Official Publications Center, Number 22, published on 18.03.2010, Law No 10 237, dated 18.02. 2010 "On occupational safety and health", pg. 672

${ }^{3}$ In implementation of the Law On occupational safety and health", the Council of Minister adopted a series of by-laws such as: CMD No 107, dated 09.02.2011 "On the structure, rules of organization and function of the Security Council for occupational health and employee representatives"; CMD No.562, dated 03.07.2013 "On the minimal requirements of safety and health when using work equipment in the work place"; CMD No.563, dated 03.07.2013 "On minimal requirements of safety and health in using work equipment in the work place"; CMD No. 564, dated 03.07.2013 "On minimal requirements of safety and health in using work equipment in the work place"

${ }^{4}$ See, : www.qpz.gov.al, Official Journal of the Republic of Albania, published by Official Publications Center, No.220, dated 22.12. 2015: "Law No. 136/2015, dated 05.12.2015 "On some extentions and amendments in the Law No. 7961, dated 12.07.1995 'Labour Code of the Republic of Albani, amended"

${ }^{5}$ See: www .ilo.org "Working together to promote a safe and healthy working environment", International Labour Conference, $106^{\text {th }}$ session, 2017, prg 30, page no 13
} 
Organization highlights the necessary attempts each country must make to avoid national problematic, to consolidate legal measures and further develop national programs in the field of occupational safety and health.

In Albania, the relevant legal framework in regard to occupational safety and health, places special importance to the aforementioned legal sources, conventions and international laws ratified by our country, which request the implementation of important legal obligations by the parties involved in the work relations, as well as the institutional interaction and collaboration between social actors in order to detect and prevent occupational injuries of employees.

The Labour Code of the Republic of Albania, amended, adopted again in 1995, in a special chapter, regulates occupational conditions providing legal obligations in the framework of workplace maintenance, hygiene, workplace area, the use of hazardous equipment, noises, vibration, heavy loads, scaffolding, as well as the regulations for workplace fire prevention. ${ }^{1}$

Regarding the implementation of measures of a general nature, the provisions if the Labour Code provide the employer's obligation to take the necessary preventive measures to protect the life and health of the employees, which includes the organization of advisory and awareness sessions for employees.

Another obligation of the employer, when the nature of the labor potentially submits employees to special risks, is to organize at his own expense periodical medical checkups. ${ }^{2}$

In respect to implementing the legal provisions for occupational safety and health, the employer is obliged to evaluate the workplace risk, as well as report it in a special document wherein he must also define the relevant measures that aim to eliminate this risk.

The defining of the employer's special obligation, with the purpose of protecting employees and preventing workplace accidents and professional illnesses constitutes a very positive novelty for our legislation in the field of occupational safety and health.

In the meantime, to answer an emergent need related to the situation created in our country because of workplace accidents especially in certain sectors of activity such as in construction, mines, agriculture, the Law "On occupational safety and health" was adopted, the provision of which aim to guarantee the protection of health through preventing dangers in the workplace by eliminating hazardous factors in the workplace, continual informing and consultation. ${ }^{3}$

\footnotetext{
${ }^{1}$ For more see "Labour Code, updated with judicial practice", Judicial Publications Albjuris, 2016, pg 45, Chp. VIII

2 See "Labour Code, updated with judicial practice", Judicial Publications Albjuris, Tirana, 2016, pg 46, Art. 40, prgrh

${ }^{3}$ See : www.qpz.gov.al, Official Journal of the Republic of Albania, published by Official Publications Center, Number 22, dated 18.03.2010, Law No. 10 237, dated 18.02. 2010 "Occupational Safety and Health", Art. 2
} 
This law ${ }^{1}$ places upon the respective parties employer and employee obligations in regard to implementing measures that aim to prevent occupational health injury of employees, however the obligations that belong to the employer are many compared to those that fall upon employees in the field of safety.

Moreover, the law contains and refers to important principles but I'd like to address (without underestimating in any way the value of other principles in the spirit of which the law is established and should be implemented) the principle that states "employees' obligations in the framework of occupational safety don't impinge on the principle of employer's responsibility", ${ }^{2}$ reinforcing the idea that employers are the party that should monitor and control the employees' implementation of their occupational safety obligations.

Another novelty that the law for occupational safety and health brings about is the establishing of the Occupational Safety and Health Council. This special institution of collaboration between parties, with the participation of representatives of employees and employers is considered an institution with advisory functions in the field of safety and health with the main goal being the prevention of workplace risks.

In this way, the provisions of this law, also aim to include employers in issues of safety and health by establishing such advisory institutions with the participation of select representatives from the ranks of employees, as well as the demand for collaboration between social actors, consequently striving to raise awareness in the employees themselves in regard to identifying and elimination negative practices in this field.

According to the data in the document of the Strategy for Occupational Safety and Health, the low rate of occupational safety and health regulations' implementation in practice by subjects seems to be caused by diverse factor, the most important ones being: poor consciousness, wrong approach and behavior, lack of information from both employers and employees, poor level of awareness, high unemployment rate, lack of stimulating mechanisms like reward, lack of technical regulations in the field of occupational safety and health, lack of consultation, lack of capacity for trainings ${ }^{3}$, etc.

\section{Administration of Labour Relations and the Role of Labour Inspection}

Among the main institutions which ensure the labour law implementation is the State Labour Inspectorate, an institution that acts based on a special law. ${ }^{4}$

\footnotetext{
${ }^{1}$ Law No. 10 237, dated 18.02. 2010 "Occupational Safety and Health" compiled based on requirements from the Framework Directive 89/391/EEC

${ }^{2}$ For more, see: www.qpz.gov.al, Official Journal of the Republic of Albania, published by Official Publications Center, Number 22, dated 18.03.2010, Law No. 10 237, dated 18.02. 2010 "Occupational Safety and Health", Art. 4, prgrh.4

${ }^{3}$ For more information regarding the strategy for occupational safety and health, see www.qpz.gov.al, Official Journal of the Republic of Albania, published by Official Publications Center, Number 90, in 2016, published on 27.05.2016, CMD No371,dt 18.05.2016 "On adopting the Political Document for occupational safety and health 2016-2020, and the action plan for its implementation"

${ }^{4}$ The State Inspectorate that covers the field of labour is the institution that ensures the labour law implementation based on Law No 9634,dt 30.10.2006 'On Labour Inspection", amended with the Law No 24/2013, dt 14.02.2013, and Law Nr 57/2017, dt 20.04.2017
} 
Beside the main mission of this organism to control and monitor the legal provisions' implementation in the framework of occupational safety, to detect violations committed by subjects of the labour law in this field, it should also face newborn problems that might stem from certain social as well as technological developments.

The widespread implementation of new technologies and new forms of work organization might reduce old risks but may also lead to new problems. ${ }^{1}$

The State Inspectorate that regulates the field of labour, also must advice, inform, prevent and impose respective sanctions depending on the violations detected by it in compliance with the provided procedure.

Just like the respective law on labour inspection provides, the main sanction is the fine that can be imposed by the Labour Inspector. ${ }^{2}$ In cases detected by Labour Inspectors where continuing the activity would constitute in immediate, considerable and inevitable risk to the employees safety and health and when their evacuation from the workplace is necessary, they take urgent measures.

Urgent measures, as defined by the law ${ }^{3}$, include interrupting the carrying out of an action or activity or a part of it, prohibiting the use of an equipment, machinery etc.

Aiming to obtain and give information in regard to implementing the legal framework on occupational safety and health, the State Inspectorate that covers the field of labour also collaborates with other state institutions, employees and employers, becoming thus an interactive organism.

In my opinion the framework of this institution's activity has to face other challenges the likes of the need to create efficient mechanisms to encourage collaboration and facilities of a technical and infrastructural nature, the need to offer the possibility for further qualifications in this field, but also to encourage the complete implementation of legal provisions that guarantee occupational safety and health.

An important role in reviewing the main problems regarding occupational safety is played by the National Labout Council, which is a three-party institution where representatives of the government, employees and employers participate. ${ }^{4}$

In accordance to the Labour Code provision, this institution acts like a main mechanism of consultation in compiling and implementing the legal framework, and it should encourage collaboration to efficiently implement policies for occupational safety and health, as a vital necessity for better conditions and results in the production activity.

\footnotetext{
1 "Glossary of labour law and industrial relations ( with special reference to the European Union)", General Editors: Gianni Arrigo, Giuseppe Casale, Geneva, International Labour Office, 2005, pg.154

2 Based on Law No. 9634,dt 30.10.2006 'On Labour Inspection”, amended by Law no. 24/2013, dt 14.02.2013, and law no. 57/2017, dt 20.04.2017, see art. 33, pg 5

${ }^{3}$ For more see: Law No. 10 433, date 16.06.2011 "On Inspection in the Republic of Albania", Article 43/2

${ }^{4}$ Creation and competencs of the National Labour Council by the "Labour Code of Albania", art. 200
} 
The policies for occupational safety and health 2016-2020 strive to improve the situation by demanding an efficient implementation of the law by evaluating the work of the Labour Inspectors, establishing a national system to manage the information, education and research processes, as well as raising public awareness and increasing social collaboration. ${ }^{1}$

The above legislative changes represent new challenge as it mostly states the 'prevention plan of measures', regardless of multiple difficulties which should be considered as well.

\section{Recommendations}

- Collaboration is one of the most efficient means to achieve the goal of eliminating negative practices such as the violation of provisions that guarantee occupational safety of life and health.

- The effective increase of collaboration between employees or their representatives and employers, including the participation of the Labor Inspectorate, would serve to identify the realistic means and manner used by employers to avoid the provisions in this field or the actual negative practices, and it would also bring about the implementation of the accurate measures in this aspect.

- Furthermore, I think that consolidating cooperation between governmental structures and the Labor Inspectorate is a necessity in regard to exchanging the necessary information as well as in creating the possibilities for further qualification of the labor inspectors.

- Raising awareness of employees in regard to their legal bound rights, including the right to be informed, advised and represented decently from the employees' organizations, I think would be an adequate mechanism to incite larger union activity.

Of course, the implementation of real measures in order to improve legal provisions' implementation in the field of occupational safety and health is linked closely to implementing efficient economic and social policies and of measures that fight negative phenomena and practices in all the aspects of implementing law. That is why I believe that the factual engagement in consolidation social dialogue and collaboration is essential to the current policies in the field of occupational safety and health.

\footnotetext{
${ }^{1}$ See www.qpz.gov.al, Official Journal of the Republic of Albania, published by Official Publications Center Number 90, of 2016, date 27.05.2016, CMD No.371,dt 18.05.2016 "On adopting the Political Document for occupational safety and health 2016-2020 , and the action plan for its implementation"
} 


\section{References}

[1] "Glossary of labour law and industrial relations (with special reference to the European Union)", General Editors: Gianni Arrigo, Giuseppe Casale, Geneva, International Labour Office, 2005

[2] International Labour Law, Third revised Edition, Jean-Michel Servais, Wolters Kluwer, Law and Business, 2011, Kluwer Law Intenational BV, Netherlands

[3] www.ilo.org/publns, ILC.106/III/1B, International Labour Conference, $106^{\text {th }}$ session, 2017 : "Working together to promote a safe and healthy working environment” pg. 2, prgh. 5, International Labour Office, Geneva

[4] www.qpz.gov.al, Official Journal of the Republic of Albania, Official Publications Center, No.220, dated 22.12. 2015: "Law No. 136/2015, dated 05.12.2015 " On some extentions and amendments in the Law No. 7961, dated 12.07.1995 'Labour Code of the Republic of Albani, amended"

[5] www.qpz.gov.al, Official Journal of the Republic of Albania, published by Official Publications Center, Number 22, dated 18.03.2010, Law No. 10 237, dated 18.02. 2010 "Occupational Safety and Health"

[6] www.qpz.gov.al, Official Journal of the Republic of Albania, published by Official Publications Center, Number 90, in 2016, published on 27.05.2016, CMD No371,dt 18.05.2016 " On adopting the Political Document for occupational safety and health 2016-2020, and the action plan for its implementation"

[7] Law No 9634,dt 30.10.2006 'On Labour Inspection", amended with the Law No 24/2013, dt 14.02.2013, and Law Nr 57/2017, dt 20.04.2017

[8] Law No. 10 433, date 16.06.2011 " On Inspection in the Republic of Albania"

[9] CMD No 107, dated 09.02.2011 "On the structure, rules of organization and function of the Security Council for occupational health and employee representatives"

[10] CMD No.562, dated 03.07.2013 "On the minimal requirements of safety and health when using work equipment in the work place"

[11] CMD No.563, dated 03.07.2013 "On minimal requirements of safety and health in using work equipment in the work place"

[12] CMD No. 564, dated 03.07.2013 "On minimal requirements of safety and health in using work equipment in the work place" 